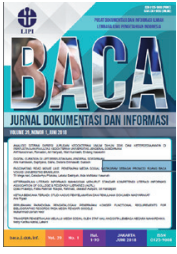

\title{
Analisis isi infografis akun resmi LINE Kementerian Komunikasi dan Informatika
}

\author{
Aulia Puspaning Galih ${ }^{1}$ \\ ${ }^{1}$ Universitas Brawijaya \\ *Korespondensi: auliapuspa@ub.ac.id
}

Diajukan: 12-01-2021; Direview: 19-02-2021; Diterima: 21-04-2021; Direvisi: 01-06-2021

\begin{abstract}
This research is conducted to find the contents of the information in the form of infographics on the official LINE account of Kemkominfo and to find whether the infographics made have fulfilled their function as a means of information repackaging. This research uses descriptive - qualitative methods with content analysis techniques without using respondents or informants as research objects. Content analysis for infographics on the official LINE Kemkominfo account was carried out for 6 months from October 2019 to March 2020. There are 9 information displays on the official LINE account of Kemkominfo: (1) latest news on the most popular issues in Indonesia; (2) information on specific themes; (3) information regarding the results of the activity conducted from government institutions; (4) information regarding Kemkominfo's clarification of news and issues circulating in public; (5) congratulatory message at certain moments; (6) quiz about knowledge related to Indonesia; (7) information regarding procedures in the management of government-related matters; (8) the game of finding words based on clues; (9) word equivalents or translate. Kemkominfo chose to use infographics to facilitate the dissemination of information to the public.
\end{abstract}

\begin{abstract}
ABSTRAK
Penelitian ini bertujuan untuk mengetahui isi informasi dalam bentuk infografis pada akun resmi LINE Kemkominfo dan mengetahui apakah infografis yang dibuat telah memenuhi fungsinya sebagai alat kemas ulang informasi. Penelitian ini menggunakan metode deskriptif - kualitatif dengan teknik analisis isi tanpa menggunakan responden ataupun informan sebagai obyek penelitian. Analisis isi untuk infografis pada akun resmi LINE Kemkominfo dilakukan selama 6 bulan pada postingan bulan Oktober 2019 - Maret 2020. Terdapat 9 sajian informasi pada akun resmi LINE Kemkominfo, yaitu: (1) berita terkini mengenai isu terpopuler di Indonesia; (2) informasi mengenai himbauan pada tema tertentu; (3) informasi mengenai hasil kerja suatu kegiatan pada lembaga pemerintahan; (4) informasi mengenai klarifikasi Kemkominfo terhadap berita-berita dan isu yang beredar; (5) ucapan selamat pada momen tertentu; (6) kuis mengenai pengetahuan seputar hal-hal terkait dengan Indonesia; (7) informasi mengenai prosedur dalam pengurusan hal-hal terkait pemerintahan; (8) permainan menemukan kata berdasarkan petunjuk; (9) padanan kata. Kemkominfo memilih menggunakan infografis untuk penyebaran informasi kepada masyarakat.
\end{abstract}

Keywords: Infographi; Information; Content analysis; Information repackaging; Kemkominfo

\section{PENDAHULUAN}

Informasi merupakan komoditas utama bagi masyarakat. Kalangan masyarakat yang membutuhkan informasi pun beragam, mulai dari pendidik hingga ibu rumah tangga. Saat ini, informasi dapat diakses dengan mudah karena sudah ada teknologi digital berupa gadget. Informasi digital jumlahnya sangat banyak, bahkan melebihi informasi tercetak (Fadilah, 2016). Banyaknya informasi yang beredar di masyarakat menyebabkan perlunya kegiatan kemas ulang informasi untuk menyajikan informasi yang lebih menarik ke masyarakat.

Salah satu bentuk kemas ulang informasi adalah infografis. Menurut Saptodewo (2014), infografis merupakan representasi visual dalam bentuk grafis informasi data atau pengetahuan, 
yang dibuat untuk menyajikan informasi kompleks secara cepat dan jelas. Bentuk infografis lebih menarik karena dilengkapi dengan gambar yang mewakili isi informasi.

Kementerian Komunikasi dan Informatika (Kemkominfo) sebagai salah satu lembaga pemerintah yang berkonsentrasi pada penyebaran informasi dan penyediaan fasilitas teknologi informasi memiliki kemampuan untuk memberikan konten informasi kepada masyarakat secara mudah dan merata. Salah satu cara untuk memperluas jangkauan informasi yaitu melalui media sosial. Media sosial merupakan media penyebaran informasi yang dapat digunakan untuk menyisipkan berbagai jenis dokumen.

Penelitian ini menganalisis akun resmi LINE dari Kemkominfo yang dapat diakses pada laman https://page.line.me/785dentq. Konten media sosial LINE Kemkominfo dapat dipertanggungjawabkan secara hukum. Masyarakat dapat dengan mudah memperoleh informasi infografis secara gratis pada akun LINE Kemkominfo setelah menambahkan di akun LINE masing-masing pengguna. Data per-Februari 2020 diketahui ada 469.266 pengikut yang dapat memanfaatkan informasi pada akun LINE Kemkominfo. Penelitian ini membahas tentang ketersediaan isi infografis pada akun resmi LINE Kemkominfo dan fungsinya dalam kemas ulang informasi.

\section{TINJAUAN PUSTAKA}

\subsection{Informasi}

Yusuf (2009) mengatakan bahwa information is a symbol or a set of symbols which has the potential for meaning, yaitu informasi adalah lambang atau seperangkat lambang yang mempunyai arti. Informasi terdiri dari informasi tidak terekam dan informasi terekam. Informasi terekam masih dibedakan antara yang tidak ilmiah dan yang ilmiah. Informasi menjadi suatu rekaman fenomena yang diamati, yang dapat juga berupa bahan keputusan yang dibuat seseorang. Informasi merupakan peristiwa, pengetahuan, rekaman data, gambar, grafik, dan dokumen yang dapat disampaikan secara lisan dan terekam yang mengandung konten pengetahuan dalam media tertentu. Informasi dalam konteks media sosial memiliki pengertian sebagai sumber utama adanya publikasi. Informasi menjadi komoditas bagi media sosial, sehingga menarik untuk diakses.

\subsection{Kemas Ulang Informasi}

Widyawan (2014) mengatakan bahwa kemas ulang informasi merupakan proses sistematik untuk memberikan nilai tambah pada informasi, dengan cara menganalisis dan mensintesis, menyunting dan memformat, serta menerjemahkan dokumen. Kemas ulang informasi menjamin keterbaruan, ketepatan, kesahihan, kelengkapan, kemudahan pemahaman, kenyamanan penggunaan, dan penyesuain informasi untuk memenuhi kebutuhan pengguna, Informasi yang dikemas kembali memberi kemudahan dalam penyebaran informasi dan temu kembali informasi.

Oyadonghan, Eke, \& Fyneman (2016) menjelaskan bahwa kemas ulang informasi merupakan pengemasan kembali dalam bentuk baru dan dalam format yang lebih menarik, sehingga dapat memenuhi kebutuhan informasi pengguna perpustakaan secara efektif. Informasi yang terkandung dalam paket kemas ulang harus dapat dipahami secara mudah. Konten kemasan informasi harus dibuat berdasarkan kebutuhan informasi pengguna. Kemas ulang informasi harus memperhatikan pemrosesan ulang dan pengemasan ulang.

Menurut Pebrianti (2015), kegiatan kemas ulang informasi memiliki fungsi teknis sebagai berikut.

- Sarana pendokumentasian informasi. Informasi memiliki bentuk lain sehingga dapat menjadi dokumentasi hasil terbitan ataupun bentuk informasi. Kemas ulang informasi dapat mempermudah temu kembali karena konten informasi yang terstruktur dapat diambil intinya sehingga mudah dipahami. 
- Sarana memilih informasi yang bermanfaat bagi pemustaka secara sistematis. Kemas ulang informasi mempertimbangkan susunan infromasi yang diproduksi terlebih dahulu. Susunan itu sebaiknya memiliki banyak kata penjelas agar isinya mudah dipahami pembaca.

- Sarana penyajian dan alih informasi yang lebih ekstensif. Bentuk informasi yang berubah diharapkan dapat menjangkau jenis pembaca yang luas dan memberikan kebebasan bagi pembaca untuk mengakses informasi tersebut. Masyarakat dapat memilih bentuk informasi yang diinginkan dengan konten informasi yang sama.

- Sebagai alat terjemahan. Seseorang memiliki cara yang berbeda-beda dalam menangkap suatu informasi. Kemas ulang informasi dapat menjadi cara alternatif bagi seseorang untuk memahami konten informasi yang disampaikan oleh penulisnya.

- Sebagai peluang untuk menerapkan hasil penelitian. Produk kemas ulang informasi merupakan hasil pengembangan hasil penelitian. Karya hasil penelitian dapat dikemas ulang dalam bentuk yang berbeda-beda dan praktis, sehingga isinya mudah dipahami oleh pembaca.

- Sarana penyajian informasi relevan secara langsung. Informasi yang baik adalah informasi dengan tingkat aktualisasinya baik berdasarkan kondisi kebutuhan masyarakat. Kemas ulang informasi diharapkan dapat menghubungkan kebutuhan masyarakat terhadap ketersediaan informasi yang ada disekitarnya.

\subsection{Infografis}

Saptodewo (2014) menjelaskan bahwa grafik informasi atau infografis adalah cara penyajian informasi, data, atau pengetahuan menggunakan alat-alat visual. Menurut Miftah, Rizal, \& Anwar (2016), infografis merupakan sebuah konsep umum yang menyajikan informasi secara kreatif, dengan mengutamakan keindahan (daya tarik), ketepatan isi dengan ilustrasi, dan keefektifan waktu yang diperlukan dalam menginterpretasikan informasi. Infografis dapat menyederhanakan informasi yang bersifat kompleks menjadi informasi praktis yang lebih mudah dipahami. Infografis juga disebut sebagai ilustrasi informasi. Infografis yang dikenal masyarakat saat ini masih fokus pada bentuk penyampaian informasi melalui grafik dan data statistik. Infografis terdiri dari komponen mendasar yaitu gambar, pemilihan warna, pemilihan simbol, dan komposisi warna dan bentuk yang digunakan sehingga informasi yang disajikan terlihat menarik dan memenuhi standar visualisasi yang dibutuhkan masyarakat.

\subsection{Media Sosial}

Mulawarman \& Nurfitri (2017) menjelaskan bahwa media sosial adalah alat komunikasi yang digunakan oleh pengguna dalam proses sosial. Menurut Fuchs (2014), media dan semua perangkat lunak merupakan "sosial" dan menjelaskan bahwa keduanya merupakan produk dari proses sosial. Eric, et al (2015) mengatakan bahwa dalam beberapa kasus, media sosial digunakan pada tiga sektor. Untuk tujuan ilustrasi, penelitian ini membahas aplikasi media sosial dalam domain pemasaran, manajemen hubungan pelanggan, berbagi pengetahuan, kegiatan kolaboratif, komunikasi organisasi, pendidikan dan pelatihan, dan sebagainya. Mengacu hal tersebut, informasi dalam media sosial dapat dibagikan secara mudah melalui perangkat lunak yang membantu memenuhi kebutuhan informasi masyarakat dalam konteks kehidupan sosial.

\section{METODE}

Hardjana (2003) mengatakan bahwa metode adalah cara berpikir secara matang yang dilakukan dengan berbagai Langkah untuk mencapai tujuan tertentu. Penelitian ini menggunakan metode deskritip - kualitatif. Menurut Wibowo (2011), metode deskriptif - kualitatif adalah penggambaran secara kualitatif dari fakta, data, atau objek material, bukan berupa rangkaian angka melainkan ungkapan bahasa atau wacana yang diinterpretasikan secara tepat dan sistematis. Peneliti menggunakan teknik analisis isi (content analysis) untuk menganalisis isi infografis pada akun LINE resmi 
Kemkominfo di laman https://page.line.me/785dentq. Akun LINE tersebut memiliki 890 post sejak 11 Juli 2017. Akun tersebut dipilih menjadi obyek penelitian karena menjadi akun resmi pertama dari institusi pemerintah Indonesia di LINE (Widia, 2017). Analisis isi untuk infografis pada akun resmi LINE Kemkominfo dilakukan selama 6 bulan pada postingan bulan Oktober 2019 - Maret 2020.

\section{HASIL DAN PEMBAHASAN}

Akun LINE Kemkominfo memiliki 469.226 pengikut per-1 Februari 2020. Penggunaan media sosial LINE ini merupakan yang pertama kali dilakukan dari oleh pemerintah Republik Indonesia. Konten utama LINE Kemkominfo adalah infografis dari isu-isu terkini dalam masyarakat Indonesia. Hal tersebut dapat dilihat pada Gambar 1.

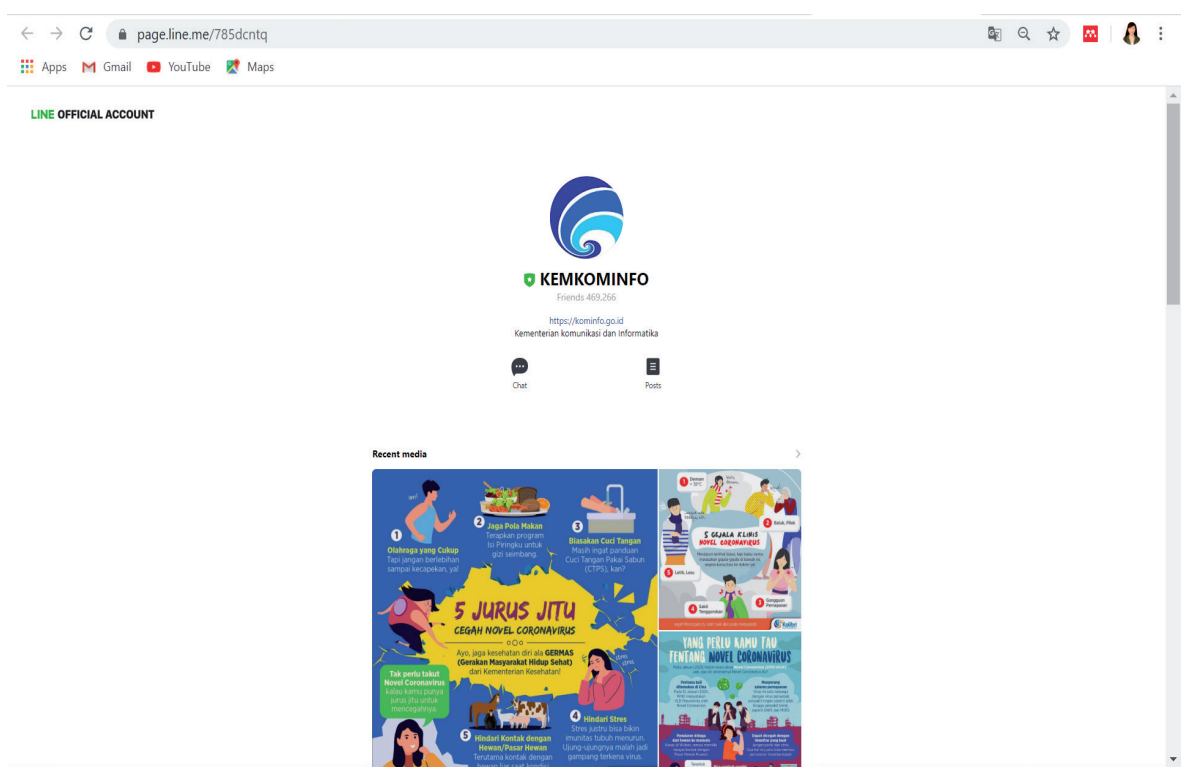

Gambar 1. Website akun resmi LINE Kemkominfo

Berdasarkan hasil pengamatan pada akun LINE Komkominfo diperoleh informasi berikut ini.

- Berita terkini mengenai isu terpopuler di Indonesia. Rubrik ini berisi mengenai informasi yang sedang hangat dimasyarakat (Gambar 2).
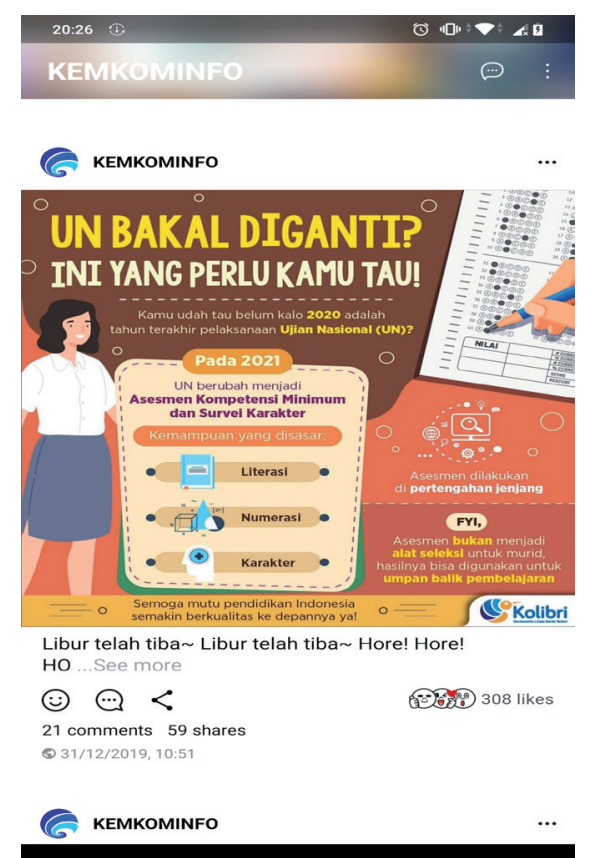

Gambar 2. Infografis mengenai ujian nasional 
- Infografis mengenai himbauan pada tema tertentu, misalnya himbauan untuk anti-radikalisme. Hal tersebut dapat dilihat pada Gambar 3.
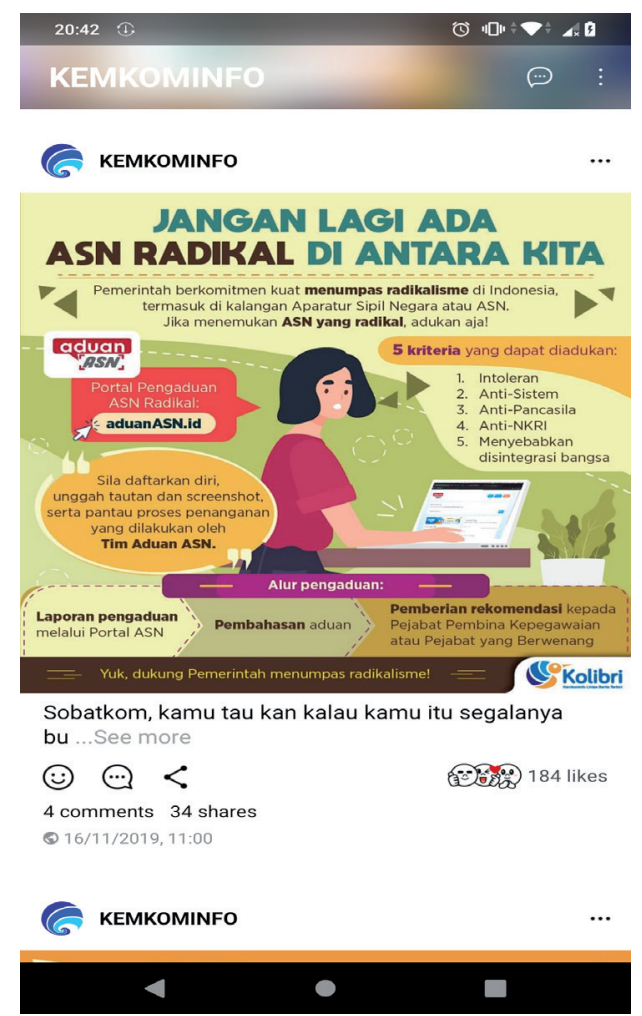

Gambar 3. Infografis mengenai himbauan anti-radikalisme

- Infografis mengenai hasil kerja suatu kegiatan pada lembaga pemerintahan, Setiap pemerintah memiliki kegiatan akan ditunjukkan transparasi secara sederhananya dalam media sosial ini. Hal tersebut dapat dilihat pada Gambar 4.

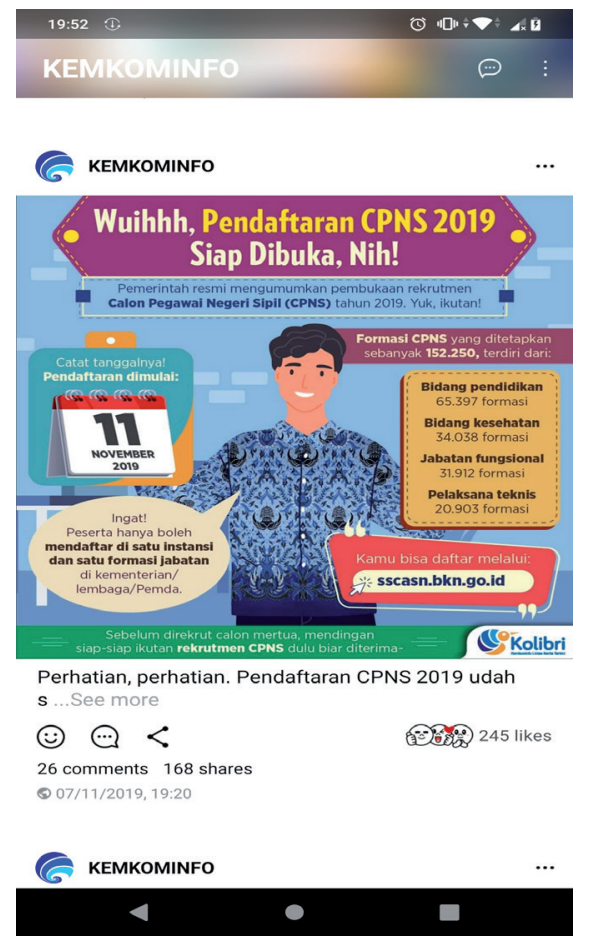

Gambar 4. Infografis mengenai pendaftaran CPNS 2019 
- Infografis mengenai klarifikasi Kemkominfo terhadap berita-berita dan isu yang beredar dan tidak terbukti kebenarannya. Hal tersebut dapat dilihat pada Gambar 5.

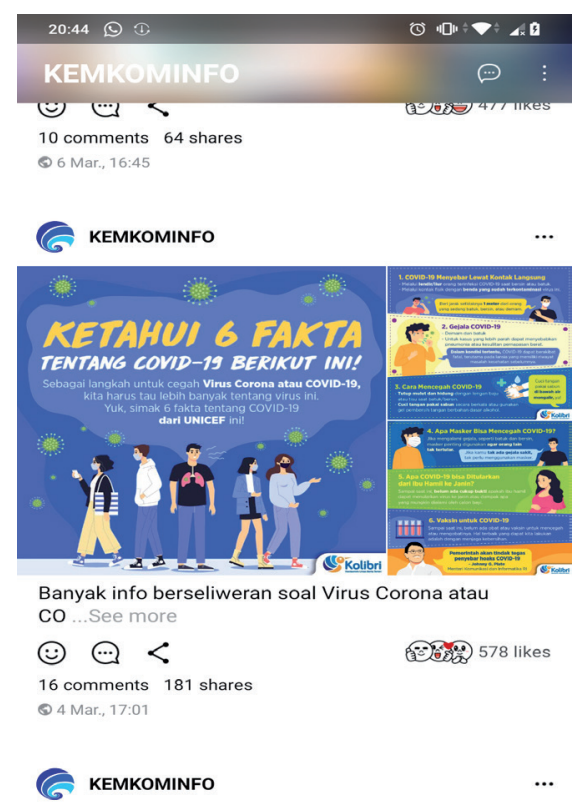

PADANAN KATA

Gambar 5. Infografis mengenai fakta Covid-19

- Ucapan selamat pada momen tertentu. Kemkominfo merupakan salah satu lembaga pemerintah maka melalui informasi ucapan ini menunjukkan dukungan pemerintah mengenai acara-acara dan peringatan yang ada dimasyarakat. Hal tersebut dapat dilihat Gambar 6 .

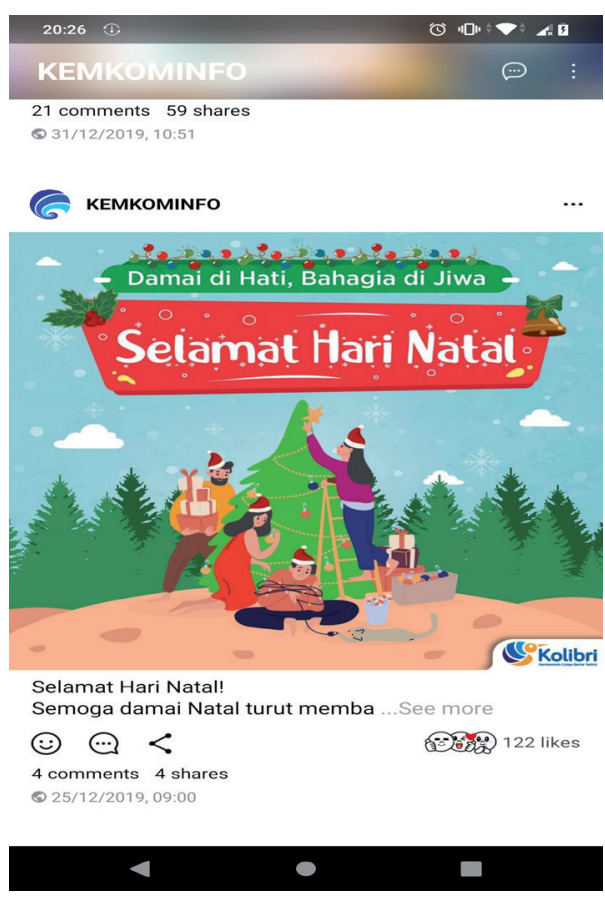

Gambar 6. Infografis mengenai ucapan hari raya keagamaan 
- Kuis mengenai pengetahuan seputar hal-hal terkait dengan Indonesia (Quiz Seru di malam Minggu). Untuk mengundang umpan balik serta menambah pengetahuan pengikut akun resmi LINE Kemkominfo maka rubrik khusus ini dibuat. Pertanyaan quiz disebarkan melalui ruang obrolan (chat room). Hal tersebut terlihat pada Gambar 7.

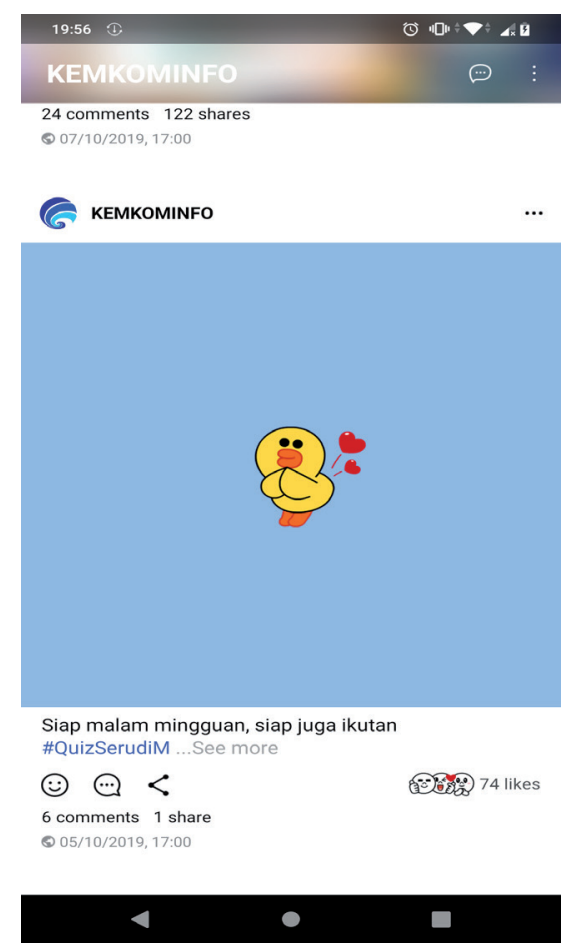

Gambar 7. Infografis Quiz Seru di Malam Minggu

- Infografis mengenai prosedur dalam pengurusan hal-hal terkait pemerintahan. Media sosial menjadi sarana menyebarkan informasi untuk meningkatkan pelayanan publik. Kemkominfo memberikan infografis berisi alur proses kegiatan pengurusan, seperti pajak, e-ktp, Kartu Indonesia Pintar, dsb. Hal tersebut terlihat pada Gambar 8.

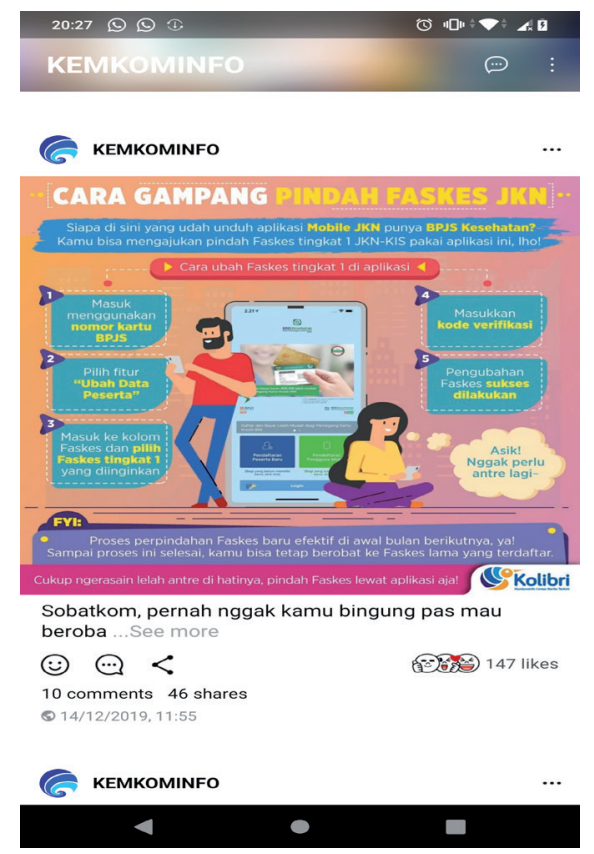

Gambar 8. Infografis mengenai cara pindah faskes JKN 
- Permainan menemukan kata berdasarkan petunjuk. Rubrik permainan memuat pertanyaan yang jawabannya dapat ditemukan dalam susunan huruf yang terpisah seperti teka-teki silang. Hal tersebut terlihat pada Gambar 9.

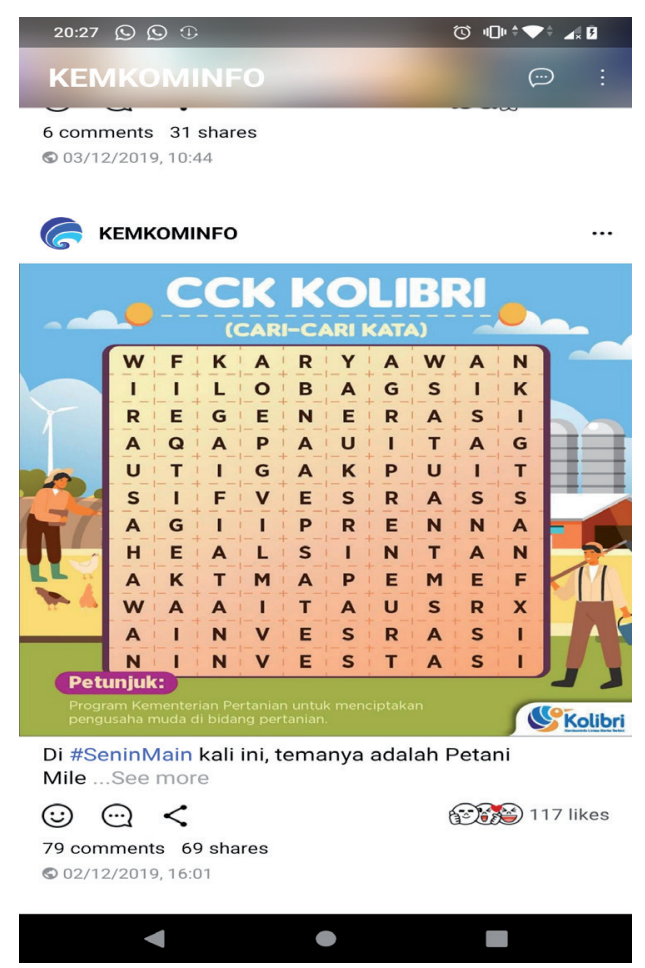

Gambar 9. Infografis mengenai permainan Cari-Cari Kata

- Padanan kata untuk istilah dari Bahasa asing yang biasa digunakan sehari-hari. Infografis ini digunakan untuk mengenalkan padanan kata baru kepada masyarakat. Hal tersebut dapat dilihat pada Gambar 10.

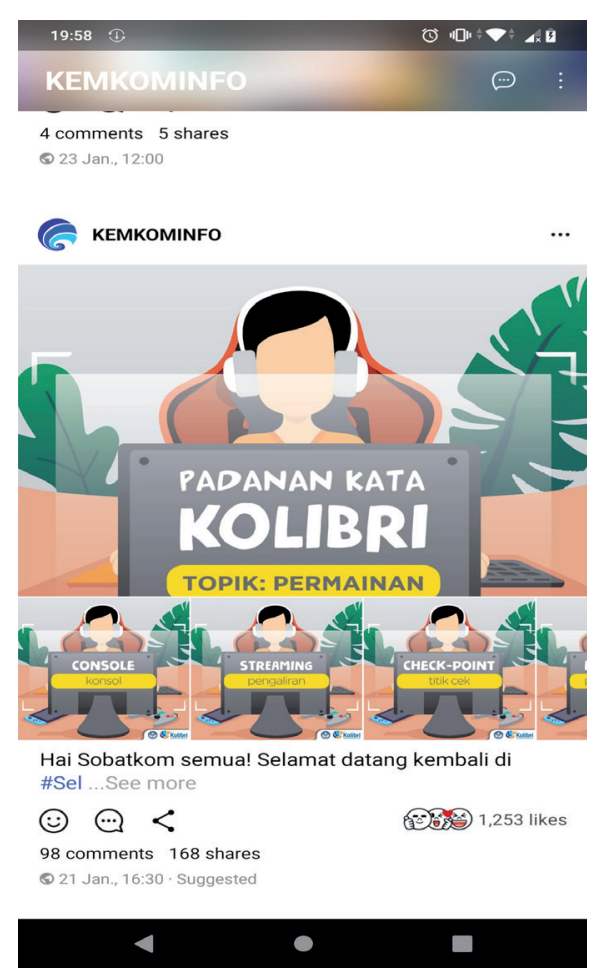

Gambar 10. Infografis mengenai padanan kata 
Secara keseluruhan konten informasi pada akun resmi LINE Kemkominfo berbentuk infografis kecuali konten yang berisi informasi hoaks. Berdasarkan fakta mengenai daya perhatian seseorang pada laman berbasis online, hanya kurang dari 5 detik seseorang dapat memutuskan untuk tertarik maupun tidak pada konten yang ada di internet. Konten infografis yang tercantum dalam akun resmi LINE Kemkominfo termasuk menarik dan mendapatkan perhatian publik.

Terdapat beberapa jenis konten infografis pada akun resmi LINE Kemkominfo selama 6 bulan (Oktober 2019 - Maret 2020), yakni sebagai berikut.

- Sarana pendokumentasian informasi. Tampilan dari infografis Kemkominfo berbasis gambar dengan teks yang mudah dipahami. Pesan diolah dalam bentuk visual sehingga bentuk teks yang kaku dapat mudah dipahami oleh masyarakat. Infografis mengenai hasil kinerja institusi pemerintahan dan prosedur yang dibutuhkan oleh masyarakat maupun institusi pemerintahan adalah hasil dari pendokumentasian informasi akun resmi LINE Kemkominfo.

- Sarana memilih informasi yang bermanfaat bagi pemustaka secara sistematis. Infografis memiliki keunggulan dari bentuk kemas ulang informasi yang lain berupa sistematika informasi yang disajikan. Dengan membaca poin-poin informasi tertentu, pembaca akan lebih mudah memahami isi infografis.

- Sarana penyajian dan alih informasi yang lebih ekstensif. Kemas ulang informasi memberikan nilai tambah pada informasi yang diproduksi. Meskipun jumlah kata semakin berkurang, efektivitas pemahaman dari pokok isi informasi akan lebih mudah tersampaikan. Isi infografis milik Kemkominfo telah mampu menjelaskan pokok pembahasan sesuai dengan tujuan yang ingin dicapai. Hal tersebut dibuktikan dengan banyaknya komentar, jumlah like dan share pada setiap postingan di media sosial LINE Kemkominfo.

- Sebagai alat terjemahan. Infografis yang diposting pada akun resmi LINE Kemkominfo telah menyajikan informasi alih bahasa (dari Bahasa Asing ke Bahasa Indonesia) dalam rubrik Padanan Kata Kolibri. Misalnya dalam kehidupan sehari-hari, orang akan lebih familiar dengan istilah mouse dalam teknologi, padahal dalam Bahasa Indonesia padanan katanya adalah tetikus. Agar masyarakat lebih mengenal istilah padanan kata yang baru tersebut maka perlu dikemas ulang menggunakan bahasa Indonesia yang mudah dipahami oleh pembaca.

- Sebagai peluang untuk menerapkan hasil penelitian. Bentuk kemas ulang informasi yang dilakukan oleh Kemkominfo merupakan penerapan hasil penelitian, terutama informasi tentang isu Covid-19. Untuk membedakan informasi actual dengan informasi hoaks, diperlukan penelitian lebih lanjut tentang informasi yang beredar di masyarakat. Konten infografis ini berisi isu yang menjadi jawaban atas permasalahan yang terjadi di masyarakat.

- Sarana penyajian informasi relevan secara langsung. Masyarakat diberikan kesempatan untuk berkomentar dalam post infografis di akun resmi LINE Kemkominfo. Hal ini bertujuan untuk mewujudkan Rencana Strategis Kemkominfo tahun 2015 - 2019 yaitu meningkatkan partisipasi publik terhadap pengambilan kebijakan publik

Kemkominfo menggunakan infografis karena informasi dalam bentuk visual lebih menarik dan mudah dipahami oleh masyarakat umum, terutama untuk memenuhi kebutuhan informasi generasi muda (Widia, 2017). Media infografis membantu peningkatan literasi masyarakat khususnya menghindari terjadinya misinformasi di masyarakat.

\section{KESIMPULAN}

Informasi pada akun resmi LINE Kemkominfo merupakan hasil kemas ulang informasi dari dokumen ataupun berita mutakhir. Infografis yang dipublikasikan pada akun resmi LINE Kemkominfo telah memenuhi fungsi kemas ulang informasi, sehingga dapat menjadi percontohan bagi lembaga 
lain untuk membuat konsep konten infografis yang dilakukan oleh Kemkominfo. Melalui konten infografis ini, diharapkan masyarakat menyadari pentingnya memahami isu-isu yang beredar di sekitar maupun di lembaga pemerintahan.

\section{DAFTAR PUSTAKA}

Fadilah, I.R. 2016. Jumlah Dokumen Informasi di Internet Sudah Melebihi Media Cetak. Tribunjabar. Id. di https://jabar.tribunnews.com/2016/04/13/jumlah-dokumen-informasi-di-internet-sudahmelebihi-media-cetak.

Fuchs, C. 2014. Social Media: A Critical Introduction. Social Media: A Critical Introduction. https:// doi.org/10.4135/9781446270066.

Hardjana, A.M. 2003. Komunikasi Intrapersonal \& Komunikasi Interpersonal. Yogyakarta: Penerbit Kanisius.

Indotelko. I. 2017. Kominfo Jangkau Millenial dengan LINE. di https://www.indotelko.com/ read/1499766762/Kominfo-Millenial-LINE pada 18 Mei 2019.

Miftah, M.N, Rizal, E., \& Anwar, R.K. 2016. Pola Literasi Visual Infografer dalam Pembuatan Informasi Grafis (Infografis). Jurnal Kajian Informasi dan Perpustakaan. https://doi.org/10.24198/jkip. v4i1.11635.

Mulawarman, M. \& Nurfitri, A.D. 2017. Perilaku Pengguna Media Sosial Beserta Implikasinya Ditinjau dari Perspektif Psikologi Sosial Terapan. Buletin Psikologi. https://doi.org/10.22146/ buletinpsikologi.22759.

Ngai, E.W.T., Moon, K.L.K., Lam, S.S., Chin, E.S.K., \& Tao, S.S.C. 2015. Social Media Models, Technologies, and Applications: An Academic Review and Case Study. Industrial Management and Data Systems. https://doi.org/10.1108/IMDS-03-2015-0075.

Oyadonghan, J.C., \& Eke, F.M., \& Fyneman, B. 2016. Information Repackaging and Its Application in Academic Libraries. International Journal of Computer Science and Information Technology Research.

Pebrianti, Y. 2015. Kemas Ulang Informasi: Kumpulan Karya Tulis Ilmiah Peneliti di Lingkup Balai Penelitian dan Pengembangan Budidaya Air Tawar (BPPBAT) Bogor. Jurnal Pari.

Saptodewo, F. 2014. Desain Infografis Sebagai Penyajian Data Menarik. Jurnal Desain.

Wibowo, W. 2011. Manajeman Kinerja. Jakarta: Raja Grafindo Persada.

Widia, S. 2017. Kominfo Punya Akun Resmi di LINE. Youngster.Id.

Widyawan, R. 2014. Agar Informasi Menjadi Lebih Seksi. Jakarta: Media Kampus Indonesia.

Yusuf, P.M. 2009. Ilmu Informasi, Komunikasi, dan Kepustakaan. 1st ed. Jakarta: Bumi Aksara. 